\title{
Parent-Infant Skin-to-Skin Contact and Stress Regulation: A Systematic Review of the Literature
}

\author{
Chiara Ionio*(D), Giulia Ciuffo and Marta Landoni \\ CRIdee, Psychology Department, Università Cattolica, del Sacro Cuore, 20123 Milan, Italy; \\ giulia.ciuffo01@icatt.it (G.C.); marta.landoni@unicatt.it (M.L.) \\ * Correspondence: chiara.ionio@unicatt.it
}

check for updates

Citation: Ionio, C.; Ciuffo, G.;

Landoni, M. Parent-Infant

Skin-to-Skin Contact and Stress Regulation: A Systematic Review of the Literature. Int. J. Environ. Res. Public Health 2021, 18, 4695. https:// doi.org/10.3390/ijerph18094695

Academic Editor: Paul B. Tchounwou

Received: 28 March 2021

Accepted: 26 April 2021

Published: 28 April 2021

Publisher's Note: MDPI stays neutral with regard to jurisdictional claims in published maps and institutional affiliations.

Copyright: (c) 2021 by the authors. Licensee MDPI, Basel, Switzerland. This article is an open access article distributed under the terms and conditions of the Creative Commons Attribution (CC BY) license (https:// creativecommons.org/licenses/by/ $4.0 /)$.

\begin{abstract}
Several studies have focused on neonatal maternal separation (MS) to investigate behavioural and neuroendocrine reactions to lack of contact, but only a few have focused on early separation in the first days or weeks after birth. This literature review investigates the vital importance of contact and touch by exploring how skin-to-skin contact (SSC) regulates stress in the mother-infant relationship. Various databases such as PubMed, Scopus, and ScienceDirect were searched for literature published between 2015 and 2020. From 1141 articles, 22 were declared eligible. The reviewed articles showed how SSC regulates child stress by biological indicators such as the autonomic nervous system (ANS), heart rate variability (HRV), cortisol, and oxytocin. This research concludes the importance of SSC for stress regulation, especially during the COVID-19 pandemic. With no research to date indicating a possible risk of neonatal COVID-19 transmission following SSC, SSC should continue to be practiced for all women, as recommended by the WHO.
\end{abstract}

Keywords: skin-to-skin contact; kangaroo care; stress; sympathetic nervous system; cortisol; newborn; systematic review

\section{Introduction}

In recent years, new knowledge in developmental psychology and infant mental health has confirmed the essential regulatory function of maternal presence [1]. In neuroscience, advanced imaging and validated autonomic nervous system (ANS) measures have provided an enhanced understanding of the interrelationship between the mother and the child's ANS [2,3].

Porges and Furman [4] were the first authors to describe the evolutionary origin of the ANS. Indeed, the earliest version of the ANS was a visceral system, the "reptilian" brain composed of a parasympathetic nervous system (PSNS). The mammalian brain's advance was the sympathetic nervous system (SNS), characterized by quick freezing, fighting, or flying [4]. However, studies have indicated how the SNS is also involved in homeostasis, even in favourable circumstances, and how it works very closely with the PSNS [4].

Furthermore, humans developed a new myelinated vagal system for prompt and precise control, connected to the cardiovascular and respiratory systems [5]. This is of particular importance for newborns. Studies have demonstrated how the old unmyelinated vagus could be mature and operative at 28 weeks. Babies born before that time could have severely impaired autonomic function. On the other hand, for babies born after 28 weeks, the PSNS could be considered relatively robust but immature until 46 to 48 weeks [6]. In particular, at 28 weeks, the response to stress for preterm babies is essentially a "reptilian" dissociation behaviour, stress-determined response [6]. These insights clearly explained how the mother's constant and uninterrupted physical presence is necessary throughout early childhood and beyond [7].

Several studies have focused on neonatal maternal separation (MS) to explore the behavioural and neuroendocrine reaction to lack of contact [8], but only a few of them concentrated on early separation in the first days or weeks after birth [9]. 
Harlow performed the first significant experiments on maternal deprivation in monkeys in the 1950s and 1970s. Afterwards, Suomi conducted similar maternal deprivation experiments on newborn monkeys [10-14], which showed how the separation of primate infants from their mothers could lead to disastrous effects on their following development and behaviour.

Considering these notions, the critical role of contact in early life days is evident.

In hospitals across the world, the practice of skin-to-skin contact (SSC) has recently started to gain more attention and importance. Early mother-infant SSC (also known as kangaroo care $[\mathrm{KC}]$ ) is a procedure characterized by the contact of the naked neonate prone on the mother's bare chest immediately after birth [15]. In the 1970s, in Bogota, the advantages of early mother-infant contact were recognized when only a few incubators were available to care for low-birthweight infants. In 2003, the World Health Organization (WHO) designated $\mathrm{KC}$ as the most effective method to maintain body temperature, stimulate senses, and provide maternal love [16].

Several studies have demonstrated the beneficial effects of SSC practice on preterm and full-term infants (e.g., enhancing the physiological, emotional, and cognitive regulatory processes) [17]. A meta-analysis by Moore et al. [17] highlighted the beneficial outcomes of SSC of breastfeeding for one to four months after birth on blood glucose, infant crying, and infant temperature control. SSC was also connected with lower salivary cortisol, lower heart rate, better sleep-wake cycles, and enhanced mood [17]. However, to date, the underlying neurobiological mechanisms are still not understood.

One explanation could be that intimate interaction and contact between mother and child addressed the infant's essential biological needs (such as warmth, touch, and smell) and hence regulated infant physiology, including the hypothalamic-pituitary-adrenal (HPA) axis [18].

Indeed, several studies have demonstrated how contact and touch are associated with the activity of the HPA axis, particularly during critical periods of development $[19,20]$. This effect is especially pronounced in the bond between the mother and the child; maternal contact has been found to reduce the infant's physiological stress [21].

The HPA axis is stimulated when threatened with stressors, and cortisol is released [22]. Although this rise helps to cope with a stressor, reactions to frequent and chronic stress can affect the body and are linked to physical and mental health issues [23,24]. SSC can enable the infant to regulate the physiology of cortisol. Studies have demonstrated how a 20-min period of mother-infant SSC was combined with a substantial reduction in preterm cortisol concentrations [25]. These results suggest that SSC might be a successful intervention to reduce infant stress [26].

Nowadays, contact is even more significant and a priority worldwide due to the COVID-19 pandemic. The novel coronavirus, COVID-19, was first reported in Wuhan, China, and was declared a pandemic by the WHO between 2019 and 2020 [27]. Indeed, it quickly became evident that COVID-19 spread rapidly between people in close contact [28]. In attempts to stem the pandemic, public health campaigns about the importance of adopting physical distance were consistent around the world.

Furthermore, the COVID-19-related restrictions on hospital procedures caused additional distress for pregnant women; in many countries, women were requested to attend all prenatal appointments alone, and in some countries, women were even asked to be alone during birth. In sum, this lack of contact could elevate the level of prenatal psychological distress for both women and their babies.

Indeed, as previously seen, touch and contact are fundamental parts of the human experience. Both are related to socio-emotional, physical, cognitive, and neurological development in childhood and necessary forms of non-biological communication throughout life [29].

When touch is limited or eliminated, it could lead to developing what is known as touch starvation [30] or touch hunger [31] connected to adverse physical and psychological outcomes. 
The current review aims to investigate and remind people of the vital importance of contact and touch.

In particular, we aim to answer the following question: "How does SSC regulate stress in an infant-parent relationship?"

In the literature, there is evidence that stimulation of specific receptors in the skin and mother-child contact increase infant vagal activity [32]. Thus, through decreased vagal tone, which dysregulates the HPA axis, a lack of caregiver touch could lead to adverse mental and physical results [33,34].

\section{Materials and Methods}

To answer the research question, we followed the Preferred Reporting Items for Systematic Review and Meta-Analysis (PRISMA) guidelines in the current review [35].

PubMed, Scopus, and ScienceDirect were used as databases to identify articles using the following research string: "skin to skin contact OR kangaroo care OR infant touch AND stress AND sympathetic nervous system OR autonomic nervous OR cortisol AND newborn OR infant AND co-regulation in the title/abstract". Records were considered eligible if articles were empirical research and peer reviewed, published in indexed scientific journals or pre-printed, written in English, published between 2015 and 2020, and answered the research question.

Two authors independently completed an inclusion/exclusion checklist while screening the titles, keywords, and abstracts of the primary search results to ensure reliability.

The search yielded 1141 articles, of which 13 were removed as duplicates. Eleven articles were added manually. After screening for abstracts and titles, 22 articles were declared eligible.

Articles that did not meet the criteria were removed from the review. The primary reason for elimination was the lack of focus on KC or SSC for stress regulation, as seen in Figure 1.

Our research question was answered by 22 articles (see Table 1).

Table 1. Features of the studies included.

\begin{tabular}{|c|c|c|c|c|}
\hline Study & Scope of the Study & Participants & Findings & $\begin{array}{c}\text { Physiological } \\
\text { Outcomes }\end{array}$ \\
\hline Butruille, 2017 [36] & $\begin{array}{l}\text { Influence of skin-to-skin } \\
\text { contact (SSC) on the } \\
\text { parasympathetic activity } \\
\text { evaluated by heart rate } \\
\text { variability (HRV) }\end{array}$ & $\begin{array}{l}\text { Twenty-two infants } \\
\text { and their mothers }\end{array}$ & $\begin{array}{l}\text { SSC had a favourable impact } \\
\text { on maternal and premature } \\
\text { infant parasympathetic } \\
\text { activities with a pronounced } \\
\text { neonate response when } \\
\text { baseline HRV values } \\
\text { were lower }\end{array}$ & HRV \\
\hline Carozza, 2020 [37] & $\begin{array}{l}\text { Brief review of how } \\
\text { contact influences the } \\
\text { development of infant } \\
\text { somatosensory, } \\
\text { autonomic, and } \\
\text { immune systems }\end{array}$ & & $\begin{array}{l}\text { Contact is an essential } \\
\text { pathway for establishing and } \\
\text { maintaining behavioural, } \\
\text { physiological, and neural } \\
\text { levels of parent-child } \\
\text { interaction synchrony }\end{array}$ & Stress \\
\hline Cleveland, 2017 [39] & $\begin{array}{l}\text { Explore the effects of } \\
\text { kangaroo care (KC) on } \\
\text { physiological functions } \\
\text { of preterm infants and } \\
\text { maternal stress. } \\
\text { Explain the effect of SSC } \\
\text { on full-term newborns }\end{array}$ & $\begin{array}{l}\text { Twenty infants were } \\
\text { assigned to the } \\
\text { experimental group } \\
\text { and } 20 \text { to the } \\
\text { control group }\end{array}$ & $\begin{array}{l}\text { KC had positive effects on } \\
\text { stabilizing infant } \\
\text { physiological functions such } \\
\text { as respiration rate and } \\
\text { reducing maternal stress. } \\
\text { Recommendations of SSC for } \\
\text { healthy newborns }\end{array}$ & $\begin{array}{l}\text { HRV and } \\
\text { maternal stress }\end{array}$ \\
\hline
\end{tabular}


Table 1. Cont.

\begin{tabular}{|c|c|c|c|c|}
\hline Study & Scope of the Study & Participants & Findings & $\begin{array}{l}\text { Physiological } \\
\text { Outcomes }\end{array}$ \\
\hline Cong, 2015 [40] & $\begin{array}{l}\text { Investigate how oxytocin } \\
\text { modulates parental stress } \\
\text { and anxiety during } \\
\text { maternal and } \\
\text { paternal SSC }\end{array}$ & $\begin{array}{l}\text { Twenty-eight stable } \\
\text { preterm infants and } \\
\text { their parents }\end{array}$ & $\begin{array}{l}\text { Both maternal and paternal } \\
\text { oxytocin levels were } \\
\text { significantly increased from } \\
\text { baseline during the SSC. } \\
\text { Both maternal and paternal } \\
\text { cortisol levels decreased } \\
\text { significantly from baseline } \\
\text { during SSC. }\end{array}$ & $\begin{array}{l}\text { Oxytocin and } \\
\text { cortisol }\end{array}$ \\
\hline Coskun, 2019 [41] & $\begin{array}{l}\text { Investigate the effects of } \\
\text { KC on the mother's } \\
\text { stress and amount of } \\
\text { milk production }\end{array}$ & $\begin{array}{l}\text { Eighty-four preterm } \\
\text { newborns and } \\
\text { their mothers }\end{array}$ & $\begin{array}{c}\mathrm{KC} \text { is effective in stimulating } \\
\text { breast milk production and } \\
\text { lowering maternal stress } \\
\text { levels. }\end{array}$ & Maternal stress \\
\hline El Farrash, 2019 [42] & $\begin{array}{l}\text { Assess the effect of } \mathrm{KC} \\
\text { and its duration on the } \\
\text { neurobehavioral system } \\
\text { and salivary cortisol }\end{array}$ & $\begin{array}{l}\text { One hundred and } \\
\text { twenty stable preterm } \\
\text { neonates }\end{array}$ & $\begin{array}{l}\text { KC improved higher scores } \\
\text { for regulation, non-optimal } \\
\text { reflexes, and movement } \\
\text { quality and lower scores for } \\
\text { handling, excitement, and } \\
\text { cortisol compared with the } \\
\text { control group }\end{array}$ & Cortisol \\
\hline Hardin, 2020 [43] & $\begin{array}{l}\text { Examine EEG patterns } \\
\text { along with basal oxytocin } \\
\text { and cortisol reactivity in } \\
\text { infants related to KC }\end{array}$ & $\begin{array}{c}\text { Thirty-three } \\
\text { mother-infant dyads at } \\
\text { neonatal and } \\
\text { three-month periods }\end{array}$ & $\begin{array}{c}\text { KC increased oxytocin levels } \\
\text { and decreased } \\
\text { cortisol reactivity. }\end{array}$ & $\begin{array}{l}\text { Oxytocin and } \\
\text { cortisol }\end{array}$ \\
\hline Harrison, 2017 [44] & $\begin{array}{l}\text { Examine SSC's effects on } \\
\text { autonomic nervous } \\
\text { system (ANS) functions }\end{array}$ & $\begin{array}{l}\text { Eighteen infants and } \\
\text { their mothers }\end{array}$ & $\begin{array}{l}\text { HRV measures suggested } \\
\text { improvements to the ANS } \\
\text { functions after SSC }\end{array}$ & HRV \\
\hline Harrison, 2019 [45] & $\begin{array}{l}\text { Investigate the effects of } \\
\text { SSC on learning and } \\
\text { autonomic functions in } \\
\text { three-month-old infants }\end{array}$ & $\begin{array}{l}\text { Ten infants with } \\
\text { congenital heart } \\
\text { disease (CHD) who } \\
\text { received neonatal SSC, } \\
16 \text { typically developing } \\
\text { (TD) infants, and } 10 \\
\text { infants with CCHD } \\
\text { without SSC }\end{array}$ & $\begin{array}{c}\text { The findings suggest } \\
\text { improvements in cognitive } \\
\text { and autonomic development } \\
\text { in three-month-old CCHD } \\
\text { infants who received } \\
\text { neonatal SSC. }\end{array}$ & HRV \\
\hline Jones et al. 2017 [46] & $\begin{array}{l}\text { Explore the effect of SSC } \\
\text { between parents and } \\
\text { their neonates on parents' } \\
\text { heart rate }(\mathrm{HR})\end{array}$ & $\begin{array}{l}\text { Twenty-six parents and } \\
\text { their babies }\end{array}$ & $\begin{array}{c}\text { A statistically significant } \\
\text { difference between the } \\
\text { parents' initial HR and HR } \\
\text { after SSC }\end{array}$ & HRV \\
\hline Kommers, 2017 [47] & $\begin{array}{c}\text { Explore whether HRV } \\
\text { could be a measure to } \\
\text { track regulatory changes } \\
\text { during KC }\end{array}$ & Eleven preterm infants & $\begin{array}{l}\text { A statistically significant } \\
\text { difference in HRV between } \\
\text { periods of } K C \text { and pre-KC }\end{array}$ & HRV \\
\hline Kommers, 2018 [48] & $\begin{array}{l}\text { Explore if a mattress that } \\
\text { mimics breathing motion } \\
\text { and heartbeat sounds can } \\
\text { have the same effects as } \\
\text { KC in preterm infants, as } \\
\text { measured by HRV }\end{array}$ & Twenty preterm infants & $\begin{array}{l}\text { HRV decreased during KC } \\
\text { and after KC. No } \\
\text { non-mattress effects } \\
\text { were reported. }\end{array}$ & HRV \\
\hline Kommers, 2018 [49] & $\begin{array}{c}\text { Explore whether KC } \\
\text { influences the salivary } \\
\text { oxytocin concentration in } \\
\text { preterm infants }\end{array}$ & Eleven twin pairs & $\begin{array}{l}\text { Preterm infant twins' } \\
\text { oxytocin concentrations } \\
\text { decreased during KC }\end{array}$ & Oxytocin \\
\hline
\end{tabular}


Table 1. Cont.

\begin{tabular}{|c|c|c|c|c|}
\hline Study & Scope of the Study & Participants & Findings & $\begin{array}{l}\text { Physiological } \\
\text { Outcomes }\end{array}$ \\
\hline Kommers et al., 2019 [50] & $\begin{array}{l}\text { Vital signs and HRV were } \\
\text { analysed during KC with } \\
\text { and without the use of a } \\
\text { swaddling device to } \\
\text { identify any } \\
\text { potential changes }\end{array}$ & Twenty preterm infants & $\begin{array}{l}\text { KC decreased heart rate, } \\
\text { respiratory rate, and HRV. } \\
\text { No changes were found } \\
\text { regarding the } \\
\text { swaddling device }\end{array}$ & HRV \\
\hline Lisanti, $2020[51]$ & $\begin{array}{l}\text { Estimate SSC's effect on } \\
\text { mothers' bio-behavioural } \\
\text { stress measures (anxiety } \\
\text { and salivary cortisol) } \\
\text { before and after neonatal } \\
\text { cardiac surgery }\end{array}$ & $\begin{array}{l}\text { Thirty women and } \\
\text { their infants }\end{array}$ & $\begin{array}{l}\text { Significant reductions in } \\
\text { self-reported anxiety and } \\
\text { salivary cortisol scores were } \\
\text { identified as a result of SSC. }\end{array}$ & Cortisol, HRV \\
\hline Mirnia et al., 2017 [52] & $\begin{array}{l}\text { Investigate the effect of } \\
\text { SSC by fathers on } \\
\text { salivary cortisol } \\
\text { of infants }\end{array}$ & $\begin{array}{l}\text { Forty-five premature } \\
\text { infants and their fathers }\end{array}$ & $\begin{array}{l}\text { SSC decreased levels of } \\
\text { cortisol in babies. }\end{array}$ & Cortisol \\
\hline Moberg, 2020 [53] & $\begin{array}{l}\text { Describe the } \\
\text { oxytocinergic system and } \\
\text { the cutaneous sensory } \\
\text { pathways activated } \\
\text { by SSC }\end{array}$ & & $\begin{array}{l}\text { Decreased stress levels could } \\
\text { be considered due to } \\
\text { oxytocin's ability to reduce } \\
\text { the amygdala's activity, the } \\
\text { HPA-axis, and the } \\
\text { sympathetic nervous system. }\end{array}$ & Oxytocin \\
\hline Morelius, 2015 [54] & $\begin{array}{l}\text { Investigate the effects of } \\
\text { SSC on salivary cortisol, } \\
\text { parental stress, } \\
\text { depression, and } \\
\text { breastfeeding }\end{array}$ & Thirty-seven families & $\begin{array}{l}\text { SSC reduces infant cortisol } \\
\text { reactivity in response to } \\
\text { treatment and improves } \\
\text { concordance between mother } \\
\text { and infant salivary } \\
\text { cortisol levels. }\end{array}$ & $\begin{array}{l}\text { Cortisol and } \\
\text { parental stress }\end{array}$ \\
\hline Pados, 2019 [26] & $\begin{array}{l}\text { Describe the } \\
\text { physiological stress } \\
\text { mechanisms that } \\
\text { contribute to infant } \\
\text { mortality and morbidity } \\
\text { in the NICU and the } \\
\text { physiological } \\
\text { mechanisms by which } \\
\text { SSC acts on the stress } \\
\text { response system }\end{array}$ & & $\begin{array}{l}\text { Importance of SSC to } \\
\text { mother-infant } \\
\text { stress regulation }\end{array}$ & Stress \\
\hline Pados et al., 2020 [55] & $\begin{array}{l}\text { Investigate if SSC is an } \\
\text { intervention used to } \\
\text { reduce stress in the NICU }\end{array}$ & & $\begin{array}{l}\text { Research supports that SSC } \\
\text { improves short-term } \\
\text { cardiorespiratory stress } \\
\text { outcomes compared with } \\
\text { incubator care. }\end{array}$ & $\begin{array}{l}\text { Stress, cortisol } \\
\text { HRV, oxytocin }\end{array}$ \\
\hline Varela, 2017 [56] & $\begin{array}{c}\text { Explore paternal } \\
\text { physiological stress } \\
\text { during SSC with their } \\
\text { babies }\end{array}$ & Forty-nine fathers & $\begin{array}{l}\text { Fathers who practiced SSC } \\
\text { showed a significant } \\
\text { reduction in physiological } \\
\text { stress outcomes. }\end{array}$ & Cortisol \\
\hline Vitnner, 2018 [57] & $\begin{array}{l}\text { Examine the relationship } \\
\text { between parental } \\
\text { involvement and salivary } \\
\text { oxytocin and cortisol } \\
\text { levels for parents } \\
\text { participating in SSC } \\
\text { intervention }\end{array}$ & $\begin{array}{l}\text { Thirty-two stable } \\
\text { preterm infants and } \\
\text { their mothers } \\
\text { and fathers }\end{array}$ & $\begin{array}{c}\text { Significant relationships exist } \\
\text { between parental } \\
\text { engagement and salivary } \\
\text { oxytocin and cortisol levels. }\end{array}$ & $\begin{array}{l}\text { Oxytocin and } \\
\text { cortisol }\end{array}$ \\
\hline
\end{tabular}




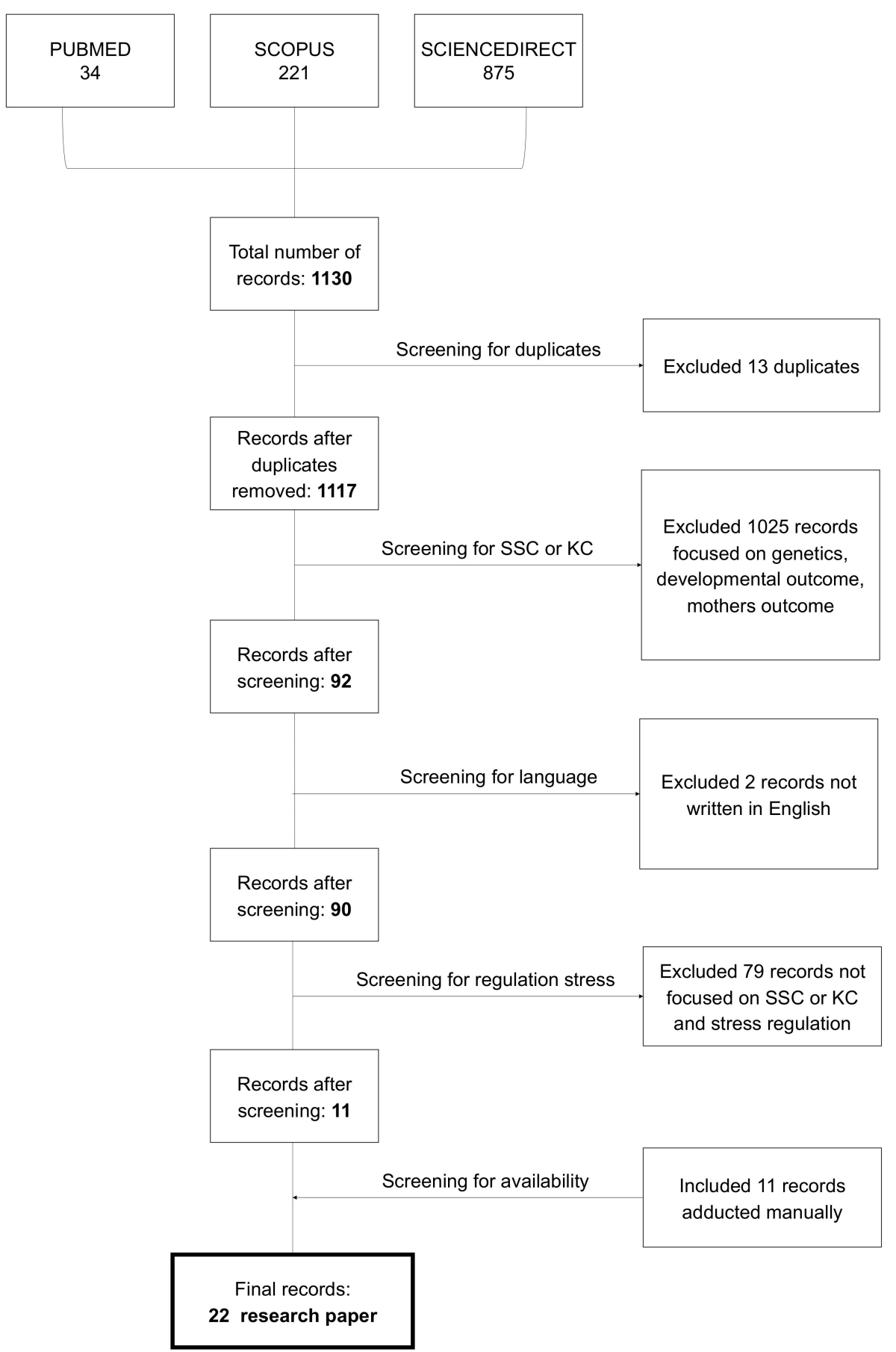

Figure 1. Flow diagram.

According to the PRISMA guidelines, the assessment of eligibility for inclusion was carried out and subsequently discussed by the authors to finalize the agreement.

\section{Results}

Our results demonstrate how stress regulation influences physiological parameters such as heart rate variability (HRV), cortisol, oxytocin, and stress levels.

Indeed, analysis of the 22 selected studies revealed that nine studies focused on HRV $[36,38,44-48,50,51]$, six studies on stress $[26,36,38,41,54,55]$, and nine on cortisol [40, $42,43,51,52,54-57]$, while the remaining six focused on oxytocin $[40,43,48,53,55,57]$. The studies are summarized in Table 1. 


\subsection{Heart Rate Variability}

HRV is a non-invasive measurement able to assess the ANS activity [58]. In the literature, studies have explained how high frequencies (over $0.15 \mathrm{~Hz}$ ) could be related to parasympathetic activity [59], compared with low frequencies connected to both the parasympathetic and the sympathetic systems [60]. Various studies have investigated the effect of SSC on stress measured by HRV. Butruille et al. [36], in a study conducted in 2017, hypothesized that SSC could potentiate maternal and neonatal parasympathetic activities. They measured HRV by referring to two specific parameters: the Analgesia Nociception Index (ANI) for mothers and the Newborn Infant Parasympathetic Evaluation (NIPE) for infants. Results showed no difference in NIPE scores between SSC and incubator care. Indeed, infants with lower parasympathetic activity before SSC reacted with an increase in NIPE during SSC, whereas those with higher parasympathetic activity at baseline did not respond significantly [36]. Similar findings were presented by Harrison et al. [44,45] in two studies. In the first one [44], the researchers conducted a two-week feasibility trial of the effects of SSC on the ANS of infants with congenital heart disease (CCHD). HRV was used as a measure for the ANS functions. Furthermore, the researchers suggested improvements in ANS function with SSC and described nonlinear HRV measures connected with ANS for the first time. In the second study [45], they found that the parasympathetic activity in both the typically developing (TD) and cardiac SSC groups decreased.

In the research series published by Kommers et al. [47-50], different results were found. In one study, no statistically significant HRV was reported [47], and significantly lower HRV was reported in the other two studies [48,49]. In response to parental co-regulation, Kommers et al. [50] suggested that a decrease of the HRV parameters during SSC should be interpreted as a positive effect of SSC and an indication of better stability.

\subsection{Maternal Stress}

In a study conducted by Cho et al. [38], maternal stress and HRV were measured before and after KC practice. KC was performed three times per week, with women instructed to remove their shirts and sterilize their chest to welcome their babies. Results demonstrated a significant reduction in stress level after KC. This outcome was supported by the results of previous studies [61]. The authors explained this drop in stress level, more direct contact of mothers with their infants, adjustment to the NICU surroundings, better communication with medical teams during $\mathrm{KC}$, and closer monitoring by babies' mums throughout KC. Similar results were found in the study of Coskun et al. [41], where mothers who performed $\mathrm{KC}$ had lower levels on the parental stressor scale.

\subsection{Cortisol}

SSC has been recognized to decrease stress reactivity in mothers and newborns. In particular, researchers have investigated salivary cortisol levels as a measure of cardiopulmonary stabilization and discovered a drop in post-birth cortisol levels of newborns treated with SSC [62]. An equal outcome was obtained in the study of El-Farrash et al. [42]. Day 7 salivary cortisol, measured as a stress response indicator for newborns, significantly decreased after $\mathrm{KC}$ compared with the conventional care group. This result demonstrated how early physical contact with the mother could impact the neuroendocrine pathways of infants.

Hardin et al. [43] found a decrease in cortisol reactivity only in the recommended-use $\mathrm{KC}$ group, indicating that consistent early KC use may be associated with an increased regulation of stress. On the contrary, Mirnia and colleagues found no statistically significant differences in stress levels measured according to salivary cortisol between infants receiving $45 \mathrm{~min}$ of SSC with their fathers and infants receiving incubator care [52]. Morelius et al. [54] performed the first study reporting salivary cortisol outcomes of preterm infants and their mothers during SSC immediately after birth. Results showed that compared with the SC group, salivary cortisol reactivity was significantly lower in the SSC group. Similarly, Vitnner and colleagues [57] found, during a 60-min SSC intervention, a decrease of salivary 
cortisol compared with baseline parameters; this finding was consistent whether the mother or father provided SSC $(p<0.001)$. Additionally, in Varela et al.'s [56] study, fathers who held their baby in SSC for the first time showed a significant decline in physiological cortisol.

\subsection{Oxytocin}

Several studies focused on oxytocin as a neurobiological mechanism connected to stress regulation. Based on a previous study, Hardin and colleagues [43] hypothesized that KC would positively impact increasing oxytocin levels in both mothers and their full-term infants and decrease infant cortisol reactivity. The results demonstrated higher levels of mother-infant dyad oxytocin in the $\mathrm{KC}$ group compared with the control group. Previous studies have theorized a bio-mechanism as an explanation of oxytocin improvement after KC [63]. Cong et al. [40] conducted the first study reporting parental salivary oxytocin and cortisol levels during maternal and paternal SSC. The results showed a growth in maternal and paternal oxytocin levels during maternal/paternal SSC (M-SSC/P-SSC), but mothers and fathers expressed different oxytocin response patterns $30 \mathrm{~min}$ after SSC. Indeed, maternal oxytocin decreased after SSC, whereas paternal oxytocin continuously remained at a higher level [40]. Meanwhile, both maternal and paternal cortisol levels decreased significantly during SSC, and afterwards, maternal cortisol decreased continuously compared with paternal cortisol, which increased after P-SSC. Such results indicated that the oxytocinergic system can modulate parent-infant relationships through oxytocin release and that maternal behaviours can further strengthen the oxytocin system in both mother and infant [40].

\section{Discussion}

Tactile sensations are the most developed sensory pathways at birth [64]. In particular, mothers provide tactile stimulation through SSC and touch, including gentle massage. The literature demonstrated how SSC (or KC) could reduce parental stress and anxiety. However, the bio-behavioural mechanism involved in this process is still unknown [16].

This review aimed to explore and investigate how SSC regulates stress in an infantparent relationship. Our results highlighted several biological mechanisms involved in parent-infant stress regulation, such as cortisol, HRV, and oxytocin.

Indeed, SSC between mothers and newborns is hypothesized to activate the infant and parent's oxytocinergic system.

In the literature, the effects of M-SSC on stress reduction have been frequently measured in infants [65], but less research has studied the effects of P-SSC on fathers' stress.

In Hardin et al.'s [43] study, for example, $\mathrm{KC}$ had moderate to significant effects on increasing oxytocin levels in mothers and infants at three months postpartum and decreasing cortisol reactivity in infants after acute stressor exposure. Identical results were obtained in the study of Cong et al. [40] and Vitnner et al. [57] for both maternal and paternal oxytocin levels. Indeed, Vitnner et al.'s study showed how parents' lower cortisol and higher oxytocin levels activated during SSC sessions were significantly related to predischarge parental involvement [57]. Furthermore, rises in oxytocin levels and concurrent decreases in cortisol levels during SSC enable both infants and parents to develop a more synchronous relationship, improving bonding and attachment opportunities, especially in the challenging NICU environment [57]. In contrast, in Kommers et al.'s [49] study, a decline of oxytocin was found for preterm infants. This outcome could be explained by higher baseline oxytocin levels, which influenced a decrease in oxytocin during KC. Another explanation could be a switch in the regulation from the sympathetic nervous system's dominance to that of the vagal systems [33]. Another crucial physiological parameter observed and connected with SSC and stress is the cortisol hormone. Indeed, it is well established that the HPA axis can control levels of cortisol, one of the most critical stress hormones. 
In the paraventricular nucleus (PVN) of the hypothalamus, corticotrophin-releasing hormone is produced and moved to the anterior pituitary, where it stimulates the release into the bloodstream of adrenocorticotrophic hormone (ACTH), which is responsible for cortisol's secretion from the adrenal cortex via the activation of ACTH receptors [66]. The HPA axis and the ANS are the essential components of the stress system, specifically the SNS, also known as the fight or flight system [67]. The most commonly used and accepted indicator for evaluating the HPA axis functioning is cortisol hormone production.

For example, Varela et al. [56] discovered a reduction in paternal cortisol levels. The psychological effects of intimate contact between the father and baby when they were close together in SSC for the first time could explain this significant reduction in physiological stress.

It is well known that premature babies' fathers are usually exposed to a very highstress level in the NICU $[68,69]$. In particular, previous studies found that holding their child in SSC leads to fathers feeling more in control of the situation and responding better to stressor events [70]. Another explanation could be that this first physical contact helps the fathers recover their role as parents and gives them a sense of control that could be very important for the future relationship [56].

The decrease in the secretion of cortisol by fathers in Varela's study [56] was consistent with the previous research conducted by Cong et al. [40], which showed that $30 \mathrm{~min}$ of SSC with a very premature infant effectively reduced the levels of salivary cortisol in fathers.

Furthermore, SSC has also been shown to decrease salivary cortisol reactivity in babies and improve the concordance between mothers' and infants' salivary cortisol levels [54]. Indeed, Morelius et al. [54] found that mothers suffered a significant decrease in cortisol levels during their first SSC or after the SSC was over but not during the intervention. This outcome was confirmed by the study of Mirnia et al. [52], where in both skin-to-skin groups and standard ward treatment groups, cortisol in neonates decreased. In particular, compared with similar time intervals in the group with usual care, the cortisol level in neonates during SSC decreased more. Additionally, the infants experienced a comparable slope in the third time interval, in which the infants were separated from their fathers' chest and received standard care, as did the control group [52].

Furthermore, in response to SSC, reduced sympathetic nervous activity is also involved in decreased heart rate and blood pressure induced by SSC.

Indeed, various studies have been conducted on SSC and heart rate variability. The dynamic, rapidly occurring changes in autonomic regulation caused by the primary $\mathrm{HR}$ control systems are reflected in the HRV. In addition to humoral factors, HR can be influenced immediately by the SNS and the PSNS [47]. Several characteristics to analyse these beat-to-beat changes were constructed and studied in adults, with at least some consensus on their interpretation. However, HRV in neonates has been less thoroughly researched.

Additionally, the neonatal heart's behaviour is significantly different from that of the adult heart, particularly in premature neonates, reflecting underlying autonomic regulation differences.

This suggests that HRV-based characteristic interpretations in neonates may differ from those of adults [47]. In Kommers et al.'s [47] study, in contrast to what would have been expected in adults, low/high frequencies (LF/HF) increased during KC. The HF power decreased significantly, probably because the deceleration was less extreme, and fewer HF components were added to the total signal. These results and previous studies indicate that the LF/HF ratio cannot capture relaxation or sympathovagal balance in preterm infants [71]. Furthermore, Cho et al. [38] showed no significant differences in the physiological effects (weight, HR, body temperature, and oxygen saturation) between preterm infants who did and did not receive KC.

These results are comparable to those previously obtained in the literature [72].

Other studies have shown different results [73]. After KC, the improved HR was due to the change in position and caused by the increased body temperature due to SSC of the infants with their mothers. 
Researchers have not only found SSC to be safe in infants with CCHD but have reported improvements in physiological parameters in these particularly vulnerable infants [44].

Despite the advantages of the practice, SSC is not always prioritized by governments and clinicians.

In an observational study by Abdulghani et al. [74], a lack of adherence to SSC practice was presented together with SSC clinicians' obstacles.

Additionally, due to concerns about the transmission of severe acute respiratory syndrome-coronavirus-2 (SARS-CoV-2), especially in the delivery room, the new coronavirus disease 2019 (COVID-19) epidemic represents the most recent and, at the same time, the most challenging obstacle for SSC.

Indeed, the COVID-19 pandemic has caused unexpected abrupt changes in several neonatal care hospital practices, including delivery room management of mothers and infants.

It is paradigmatic that during the COVID-19 emergency, SSC between the mother and her neonate is no longer permitted in many hospitals in Italy, the United States, and other countries worldwide.

However, in the literature, no significant concerns about SSC were raised during the 2009 H1N1 (swine flu) or the SARS and Middle East respiratory syndrome (MERS) epidemics, as no significant changes were advocated in infant feeding practices [75].

The worldwide recommendations on SSC were controversial at the outset of the current pandemic.

Indeed, during the COVID-19 pandemic, SSC has sometimes been supported, but most of the time it is contraindicated or simply omitted [76,77].

The WHO has published detailed guidance recommending that infants and mothers with suspected or confirmed COVID-19 "should be enabled to remain together and practice skin-to-skin contact, kangaroo care and to remain together and to practice rooming-in throughout the day and night" [78].

In contrast, the Centers for Disease Control of the United States advised, "consider separating the mother from her child temporarily" until the mother is no longer considered contagious. Furthermore, it suggested that the healthcare team discuss "the risks and benefits of temporary separation" without more profound elaboration.

The advantage of separation is that during hospitalization, it minimizes the risk of COVID-19 transmission from mother to infant. However, if the goal is the health and well-being of both mother and child, additional factors must be considered.

First, the interruption of SSC disrupts newborns' physiology. Children who are separated from their mothers have higher heartbeat rates and respiration and lower glucose levels than children who receive SSC [79]. As reported by the Royal College of Obstetricians and Gynecologists, "routine precautionary separation of a mother and a healthy baby should not be carried out lightly, given the possible harmful effects on feeding and bonding" [80].

Furthermore, isolation is a significant stressor for newborn infants and could worsen the condition's progression for those infants previously infected with COVID-19. Additionally, for mothers, isolation could be perceived as a significant stressor. Indeed, in the NICU, during SSC, their HR, salivary cortisol levels, and stress scores decreased [81].

Separating mothers from their infants can cause significant suffering, particularly in the context of being diagnosed with a pandemic disease, and the associated physiological stress could worsen the mother's condition. However, as reviewed here, the available evidence shows that maternal separation's psychological outcomes are more significant than the potential harms of maternal SSC in terms of the proximity of SARS-CoV-2. Similar considerations have been undertaken by many governments, hospitals, and researchers that decided to keep mothers and infants together, supporting SSC.

Where policies or other circumstances prevent infants from being placed after birth in SSC, maintaining proximity to their mothers, or breastfeeding, health servers have an ethical duty to improve the advice [82]. 


\section{Conclusions}

The current evidence on the effects of SSC on stress regulation is summarized in this review. In this study, the results we reviewed reflect that SSC can regulate the stress, anxiety, and psychological distress of both the mother and the infant.

During COVID-19, scientific societies are expected to legitimize and integrate SSC into their clinical practice indices based on new knowledge on the perinatal area and recently decided by the Italian Society of Neonatology [83].

Further steps towards its implementation will be needed after SSC is incorporated into clinical guidelines and protocols. In conclusion, considering that no data to date supports an increased risk of neonatal COVID-19 infection following SSC or delivery of a COVID-19-positive mother, it should be advised that SSC continue to be practiced as recommended by the WHO for all women [78].

Author Contributions: Conceptualization, C.I. and M.L.; methodology, M.L.; validation C.I., G.C., M.L.; formal analysis C.I. and M.L.; investigation, C.I. and M.L.; Writing-Original draft preparation, C.I. and M.L.; Writing-Review and editing, C.I., G.C. and M.L. All authors have read and agreed to the published version of the manuscript.

Funding: This research received no external funding.

Institutional Review Board Statement: Not applicable.

Informed Consent Statement: Not applicable.

Data Availability Statement: Not applicable.

Conflicts of Interest: The authors declare no conflict of interest.

\section{References}

1. Feldman, R. The development of regulatory functions from birth to 5 years: Insight from premature infants. Child Dev. 2009, 80, 544-561. [CrossRef] [PubMed]

2. Bergamn, L.; Linley, L.; Fawcus, S. Randomized controlled trial of skin-to-skin contact from birth versus conventional incu-bator for physiological stabilization in 1200- to 2199-gram newborns. Acta Paediatr. 2004, 93, 779-785. [CrossRef]

3. Morgan, B.E.; Horn, A.R.; Bergman, N.J. Should Neonates Sleep Alone? Biol. Psychiatry 2011, 70, 817-825. [CrossRef] [PubMed]

4. Porges, S.W.; Furman, S.A. The early development of the autonomic nervous system provides a neural platform for social behaviour: A polyvagal persective. Infant. Child Dev. 2011, 20, 106-118. [CrossRef]

5. Porges, S.W. The polyvagal perspective. Biol. Psychol. 2007, 74, 116-143. [CrossRef]

6. Haraldsdottir, K.; Watson, A.M.; Goss, K.N.; Beshish, A.G.; Pegelow, D.F.; Palta, M.; Tetri, L.H.; Barton, G.P.; Brix, M.D.; Centanni, R.M.; et al. Impaired autonomic function in adolescents born preterm. Physiol. Rep. 2018, 6, e13620. [CrossRef] [PubMed]

7. Hofer, M.A. Early relationships as regulators of infant physiology and behaviour. Acta Paediatr. 1994, 397, 9-18. [CrossRef]

8. Bergman, N.J. Birth practices: Maternal-neonate separation as a source of toxic stress. Birth Defects Res. 2019, 111, 1087-1109. [CrossRef]

9. Widström, A.; Brimdyr, K.; Svensson, K.; Cadwell, K.; Nissen, E. Skin-to-skin contact the first hour after birth, underlying implications and clinical practice. Acta Paediatr. 2019, 108, 1192-1204. [CrossRef]

10. Harlow, H.F. The Nature of Love. Am. Psychol. 1958, 13, 673. [CrossRef]

11. Harlow, H.F. Mice, monkeys, men, and motives. Psychol. Rev. 1953, 60, 23-32. [CrossRef]

12. Harlow, H.F.; Suomi, S.J. Social Recovery by Isolation-Reared Monkeys. Proc. Natl. Acad. Sci. USA 1971, 68, 1534-1538. [CrossRef] [PubMed]

13. Harlow, H.F.; Zimmermann, R.R. Affectional Response in the Infant Monkey: Orphaned baby monkeys develop a strong and persistent attachment to inanimate surrogate mothers. Science 1959, 130, 421-432. [CrossRef]

14. Suomi, S.J. Early determinants of behaviour: Evidence from primate studies. Br. Med. Bull. 1997, 53, 170-184. [CrossRef]

15. Abdulghani, N.; Edvardsson, K.; Amir, L.H. Worldwide prevalence of mother-infant skin-to-skin contact after vaginal birth: A systematic review. PLoS ONE 2018, 13, e0205696. [CrossRef]

16. Arnon, S.; Diamant, C.; Bauer, S.; Regev, R.; Sirota, G.; Litmanovitz, I. Maternal singing during kangaroo care led to auto-nomic stability in preterm infants and reduced maternal anxiety. Acta Paediatr. 2014, 103, 1039-1044. [CrossRef] [PubMed]

17. Moore, E.R.; Anderson, G.C.; Bergman, N.; Dowswell, T. Early Skin-to-Skin Contact for Mothers and Their Healthy New-Born Infants. Cochrane Database of Systematic Reviews. 2012. Available online: https://www.cochranelibrary.com/cdsr/doi/10.100 2/14651858.CD003519.pub4/full (accessed on 21 January 2021). 
18. Feldman, R.; Rosenthal, Z.; Eidelman, A.I. Maternal-pre-term skin-to-skin contact enhances child physiologic organization and cognitive control across the first 10 years of life. Biol. Psychiatry 2014, 75, 56-64. [CrossRef] [PubMed]

19. Smotherman, W.P.; Hunt, L.E.; McGinnis, L.M.; Levine, S. Mother-infant separation in group-living rhesus macaques: A hormonal analysis. Dev. Psychobiol. 1979, 12, 211-217. [CrossRef] [PubMed]

20. Acolet, D.; Modi, N.; Giannakoulopoulos, X.; Bond, C.; Weg, W.; Clow, A.; Glover, V. Changes in plasma cortisol and catecholamine concentrations in response to massage in preterm infants. Arch. Dis. Child. 1993, 68, 29-31. [CrossRef]

21. Feldman, R.; Singer, M.; Zagoory, O. Touch attenuates infants' physiological reactivity to stress. Dev. Sci. 2010, 13, 271-278. [CrossRef] [PubMed]

22. Jansen, J.; Beijers, R.; Riksen-Walraven, M.; de Weerth, C. Cortisol reactivity in young infants. Psychoneuroendocrinology 2010, 35, 329-338. [CrossRef]

23. Herman, J.P. Neural control of chronic stress adaptation. Front. Behav. Neurosci. 2013, 7, 61. [CrossRef] [PubMed]

24. Lupien, S.J.; McEwen, B.S.; Gunnar, M.R.; Heim, C. Effects of stress throughout the lifespan on the brain, behaviour and cognition. Nat. Rev. Neurosci. 2009, 10, 434-445. [CrossRef]

25. Gitau, R.; Modi, N.; Gianakoulopoulos, X.; Bond, C.; Glover, V.; Stevenson, J. Acute effects of maternal skin-to-skin contact and massage on saliva cortisol in preterm babies. J. Reprod. Infant Psychol. 2002, 20, 83-88. [CrossRef]

26. Pados, B.F. Physiology of Stress and Use of Skin-to-Skin Care as a Stress-Reducing Intervention in the NICU. Nurs. Women's Heal. 2019, 23, 59-70. [CrossRef]

27. World Health Organization. Mental Health and Psychosocial Considerations during the COVID-19 Outbreak. 18 March 2020. Available online: https:/ /apps.who.int/iris/bitstream/handle/10665/331490/WHO-2019-nCoV-MentalHealth-2020.1-eng.pdf? sequence $=1 \&$ is Allowed $=y$ (accessed on 21 January 2021).

28. Nussbaumer-Streit, B.; Mayr, V.; Dobrescu, A.I.; Chapman, A.; Persad, E.; Klerings, I.; Wagner, G.; Siebert, U.; Ledinger, D.; Zachariah, C.; et al. Quarantine alone or in combination with other public health measures to control COVID-19: A rapid review. Cochrane Database Syst. Rev. 2020, 4, 013574. [CrossRef]

29. Hertenstein, M.J.; Keltner, D.; App, B.; Bulleit, B.A.; Jaskolka, A.R. Touch communicates distinct emotions. Emotion 2006, 6, 528-533. [CrossRef] [PubMed]

30. Pierce, S. Touch Starvation is a Consequence of COVID-19's Physical Distancing. Texas Medical Centre Retrieved. Available online: https:/ / www.tmc.edu/news/2020/05/touch-starvation (accessed on 21 January 2021).

31. Mortenson Burnside, I. Touch is talking. Am. J. Nurs. 1973, 73, 2060-2063.

32. Field, T.; Diego, M. Vagal activity, early growth and emotional development. Infant Behav. Dev. 2008, 31, 361-373. [CrossRef] [PubMed]

33. Porges, S.W. The polyvagal theory: Phylogenetic substrates of a social nervous system. Int. J. Psychophysiol. 2001, 42, 123-146. [CrossRef]

34. Thayer, J.F.; Sternberg, E. Beyond Heart Rate Variability: Vagal Regulation of Allostatic Systems. Ann. N. Y. Acad. Sci. 2006, 1088, 361-372. [CrossRef] [PubMed]

35. Moher, D.; Shamseer, L.; Clarke, M.; Ghersi, D.; Liberati, A.; Petticrew, M.; Shekelle, P.; Stewart, L.A. Preferred reporting items for systematic review and meta-analysis protocols (PRISMA-P) 2015 statement. Syst. Rev. 2015, 4, 1. [CrossRef] [PubMed]

36. Butruille, L.; Blouin, A.; De Jonckheere, J.; Mur, S.; Margez, T.; Rakza, T.; Storme, L. Impact of skin-to-skin contact on the autonomic nervous system in the pre-term infant and his mother. Infant. Behav. Dev. 2017, 49, 83-86. [CrossRef]

37. Carozza, S.; Leong, V. The role of caregiver touch in early neurodevelopment and parent- infant interactional synchrony. PsyArXiv Prepr. 2020. [CrossRef]

38. Cho, E.S.; Kim, S.J.; Kwon, M.S.; Cho, H.; Kim, E.H.; Jun, E.M.; Lee, S. The effects of the kangaroo care in the neonatal inten-sive care unit on the physiological functions of preterm infants, maternal-infant attachment and maternal stress. J. Pediatr. Nurs. 2016, 31, 430-438. [CrossRef]

39. Cleveland, L.; Hill, C.M.; Pulse, W.S.; DiCioccio, H.C.; Field, T.; White-Traut, R. Systematic Review of Skin to Skin Contact for full term, healthy newborns. J. Obstet. Gynecol. Neonatal. Nurs. 2017, 46, 857-869. [CrossRef] [PubMed]

40. Cong, X.; Ludington-Hoe, S.M.; Hussain, N.; Cusson, R.M.; Walsh, S.; Vazquez, V.; Briere, C.-E.; Vittner, D. Parental oxytocin responses during skin-to-skin contact in pre-term infants. Early Hum. Dev. 2015, 91, 401-406. [CrossRef]

41. Coşkun, D.; Günay, U. The Effects of Kangaroo Care Applied by Turkish Mothers who Have Premature Babies and Cannot Breastfeed on Their Stress Levels and Amount of Milk Production. J. Pediatr. Nurs. 2020, 50, e26-e32. [CrossRef]

42. El-Farrash, R.A.; Shinkar, D.M.; Ragab, D.A.; Salem, R.M.; Saad, W.E.; Farag, A.S.; Salama, D.H.; Sakr, M.F. Longer duration of kangaroo care improves neurobehavioral performance and feeding in preterm infants: A randomized controlled trial. Pediatr. Res. 2019, 87, 683-688. [CrossRef] [PubMed]

43. Hardin, J.S.; Jones, N.A.; Mize, K.D.; Platt, M. Parent training with Kangaroo Care Impacts Infant Neurophysiological Development and Mother- Infant Neuroendocrine Activity. Infant. Behav. Dev. 2020, 58, 101416. [CrossRef] [PubMed]

44. Harrison, T.M.; Brown, R. Autonomic Nervous System Function after a skin to skin contact intervention in infants with con-genital heart disease. J. Cardiovasc. Nurs. 2017, 32, E1-E13. [CrossRef] [PubMed]

45. Harrison, T.M.; Chen, C.-Y.; Stein, P.; Brown, R.; Heathcock, J.C. Neonatal Skin-to-Skin Contact: Implications for Learning and Autonomic Nervous System Function in Infants With Congenital Heart Disease. Biol. Res. Nurs. 2019, 21, 296-306. [CrossRef] 
46. Jones, H.; Santamaria, N. Physiological benefits to parents from undertaking skin to skin contact with their neonate, in a ne-onatal intensive special care unit. Scand. J. Caring Sci. 2017, 32, 1012-1017. [CrossRef]

47. Kommers, D.R.; Joshi, R.; van Pul, C.; Atallah, L.; Feijs, L.; Oei, G.; Oetomo, S.B.; Andriessen, P. Features of Heart Rate Variability Capture Regulatory Changes During Kangaroo Care in Preterm Infants. J. Pediatr. 2017, 182, 92-98.e1. [CrossRef]

48. Kommers, D.; Joshi, R.; Van Pul, C.; Feijs, L.; Oei, G.; Oetomo, S.B.; Andriessen, P. Unlike Kangaroo care, mechanically simulated Kangaroo care does not change heart rate variability in preterm neonates. Early Hum. Dev. 2018, 121, 27-32. [CrossRef] [PubMed]

49. Kommers, D.; Broeren, M.; Oei, G.; Feijs, L.; Andriessen, P.; Bambang Oetomo, S. Oxytocin levels in the saliva of preterm in-fant twins during Kangaroo care. Biol. Psychol. 2018, 137, 18-23. [CrossRef] [PubMed]

50. Kommers, D.R.; Joshi, R.; Van Pul, C.; Feijs, L.; Oetomo, S.B.; Andriessen, P. Changes in autonomic regulation due to Kangaroo care remain unaffected by using a swaddling device. Acta Paediatr. 2018, 108, 258-265. [CrossRef]

51. Lisanti, A.J.; Demianczyk, A.C.; Costarino, A.; Vogiatzi, M.G.; Hoffman, R.; Quinn, R.; Chittams, J.L.; Medoff-Cooper, B. Skin-toSkin Care Is a Safe and Effective Comfort Measure for Infants Before and After Neonatal Cardiac Surgery. Pediatr. Crit. Care Med. 2020, 21, e834-e841. [CrossRef] [PubMed]

52. Mirnia, K.; Bostanabad, M.A.; Asadollahi, M.; Razzaghi, M.H.; Assadollahi, M. Paternal Skin-to-Skin Care and its Effect on Cortisol Levels of the Infants. Iran. J. Pediatr. 2017, 27, e8151. [CrossRef]

53. Moberg, K.U.; Handlin, L.; Petersson, M. Neuroendocrine mechanisms involved in the physiological effects caused by skin-to-skin contact-With a particular focus on the oxytocinergic system. Infant Behav. Dev. 2020, 61, 101482. [CrossRef] [PubMed]

54. Mörelius, E.; Örtenstrand, A.; Theodorsson, E.; Frostell, A. A randomised trial of continuous skin-to-skin contact after pre-term birth and the effects on salivary cortisol, parental stress, depression, and breastfeeding. Early Hum. Dev. 2015, 91, 63-70. [CrossRef]

55. Pados, B.F.; Hess, F. Systematic Review of the Effects of Skin-to-Skin Care on Short-Term Physiologic Stress Outcomes in Pre-term Infants in the Neonatal Intensive Care Unit. Adv. Neonatal. Care 2020, 20, 48-58. [CrossRef]

56. Varela, N.; Tessier, R.; Tarabulsy, G.; Pierce, T. Cortisol and blood pressure levels decreased in fathers during the first hour of skin-to-skin contact with their premature babies. Acta Paediatr. 2018, 107, 628-632. [CrossRef] [PubMed]

57. Vittner, D.; Butler, S.; Smith, K.; Makris, N.; Brownell, E.; Samra, H.; McGrath, J. Parent Engagement Correlates With Parent and Preterm Infant Oxytocin Release During Skin-to-Skin Contact. Adv. Neonatal. Care 2019, 19, 73-79. [CrossRef] [PubMed]

58. Akselrod, S.; Gordon, D.; Ubel, F.A.; Shannon, D.C.; Berger, A.C.; Cohen, R.J. Power spectrum analysis of heart rate fluctuation: A quantitative probe of beat-to-beat cardiovascular control. Science 1981, 213, 220-222. [CrossRef]

59. Saul, J.P.; Berger, R.D.; Albrecht, P.; Stein, S.P.; Chen, M.H.; Cohen, R.J. Transfer function analysis of the circulation: Unique insights into cardiovascular regulation. Am. J. Physiol. Circ. Physiol. 1991, 261, H1231-H1245. [CrossRef]

60. Camm, A.J.; Malik, M.; Bigger, J.T.; Breithardt, G.; Cerutti, S.; Cohen, R.J.; Singer, D. Heart rate variability: Standards of measurement physiological interpretation and clinical use. Task force of the European society of cardiology and the North American society of pacing and electrophysiology. Circulation 1996, 93, 1043-1065.

61. Feldman, R.; Eidelman, A.I.; Sirota, L.; Weller, A. Comparison of Skin-to-Skin (Kangaroo) and Traditional Care: Parenting Outcomes and Preterm Infant Development. Pediatrics 2002, 110, 16-26. [CrossRef] [PubMed]

62. Takahashi, Y.; Tamakoshi, K.; Matsushima, M.; Kawabe, T. Comparison of salivary cortisol, heart rate, and oxygen satu- ration between early skin-to-skin contact with different initiation and duration times in healthy, full-term infants. Early Hum. Dev. 2011, 87, 151-157. [CrossRef] [PubMed]

63. Feldman, R. Maternal-infant contact and child development: Insights from the kangaroo care intervention. In Low-Cost Approaches to Promote Physical and Mental Health: Theory, Research, and Practice; L'Abate, L., Ed.; Springer Science and Business Media: New York, NY, USA, 2007; pp. 323-351.

64. Clark-Gambelunghe, M.B.; Clark, D.A. Sensory Development. Pediatr. Clin. North Am. 2015, 62, 367-384. [CrossRef] [PubMed]

65. Cong, X.; Ludington-Hoe, S.M.; Walsh, S. Randomized cross over trial of kangaroo care to reduce biobehavioral pain re-sponses in preterm infants: A pilot study. Biol. Res. Nurs. 2011, 13, 201-216. [CrossRef] [PubMed]

66. Handlin, L.; Jonas, W.; Petersson, M.; Ejdebäck, M.; Ransjö-Arvidson, A.B.; Nissen, E.; Uvnäs-Moberg, K. Effects of sucking and skin-to-skin contact on maternal ACTH and cortisol levels during the second day postpartum-influence of epidural analgesia and oxytocin in the perinatal period. Breastfeed Med. 2009, 4, 207-220. [CrossRef] [PubMed]

67. Guilliams, T.G.; Edwards, L. Chronic stress and the HPA axis. Standard 2010, 9, 1-12.

68. Arockiasamy, V.; Holsti, L.; Albersheim, S. Fathers' Experiences in the Neonatal Intensive Care Unit: A Search for Control. Pediatrics 2008, 121, e215-e222. [CrossRef]

69. Lundqvist, P.; Westas, L.H.; Hallström, I. From distance toward proximity: Fathers lived experience of caring for their pre-term infants. Pediatr. Nurs. 2007, 22, 490-497. [CrossRef]

70. Blomqvist, Y.T.; Rubertsson, C.; Kylberg, E.; Jöreskog, K.; Nyqvist, K.H. Kangaroo Mother Care helps fathers of preterm in-fants gain confidence in the paternal role. J. Adv. Nurs. 2012, 68, 1988-1996. [CrossRef]

71. Cong, X.; Cusson, R.M.; Walsh, S.; Hussain, N.; Ludington-Hoe, S.M.; Zhang, D. Effects of skin-to-skin contact on auto-nomic pain responses in preterm infants. J. Pain 2012, 13, 636-645. [CrossRef]

72. Lee, J.; Bang, K.S. The effects of kangaroo care on maternal self-esteem and pre- mature infants' physiological stability. Korean Women Health 2011, 17, 454-462. [CrossRef] 
73. Begum, E.A.; Bonno, M.; Ohtani, N.; Yamashita, S.; Tanaka, S.; Yamamoto, H.; Kawai, M.; Komada, Y. Cerebral oxygenation responses during kangaroo care in low birth weight infants. BMC Pediatr. 2008, 8, 51. [CrossRef] [PubMed]

74. Abdulghani, N.; Amir, L.H.; Edvardsson, K. Observational study found that skin-to-skin contact was not common after vaginal birth in Saudi Arabia. Acta Paediatr. 2020, 109, 1681-1682. [CrossRef]

75. Central Disease Control and Prevention (CDC). H1N1 Flu (Swine Flu) and Feeding your Baby: What Parents Should Know. 2009. Available online: https://www.cdc.gov/h1n1flu/infantfeeding.htm (accessed on 25 June 2020).

76. The American Academy of Pediatrics Updates Guidance on Care of Newborn to Mothers COVID-19. Available online: https:/ / services.aap.org/en/news-room/news-releases/aap/2020/the-american-academy-of-pediatrics-updates-guidanceon-care-of-newborns-to-mothers-with-covid-19/ (accessed on 21 January 2021).

77. Propositions de la Socieéteé Francaise de Neéonatalogie \& de la Socieéte Francaise de Peédiatrie Concernant les Nouveau-Neés dans le Contexte D'eépidemie aà Covid-19. Available online: https:/ / f4ed7074-25ed-461c (accessed on 21 January 2021).

78. World Health Organization. New Research Highlights Risks of Separating Newborns from Mothers during COVID-19 Pandemic. Available online: https:/ / www.who.int/news/item/16-03-2021-new-research-highlights-risks-of-separating-newborns-frommothers-during-covid-19-pandemic (accessed on 21 January 2021).

79. Stuebe, A. Should Infants Be Separated from Mothers with COVID-19? First, Do No Harm. Breastfeed. Med. 2020, 15, 351-352. [CrossRef]

80. Royal College of Midwives; Royal College of Obstetricians and Gynaecologists; Royal College of Paediatrics and Child Health. Coronavirus (COVID-19) Infection in Pregnancy: Information for Health Care Professionals. Version 5. Available online: https: / / www.rcog.org.uk/globalassets / documents/guidelines/2020-03-28-covid19-pregnancy-guidance.pdf (accessed on 31 March 2020).

81. Morelius, E.; Theodorsson, E.; Nelson, N. Salivary cortisol and mood and pain profiles during skin-to-skin care for an unse-lected group of mothers and infants in neonatal intensive care. Pediatrics 2005, 116, 1105-1113. [CrossRef] [PubMed]

82. Gribble, K. Promoting attachment in foster parents: What we can learn from the experience of parents of premature infants. Adopt. Fostering 2016, 40, 113-127. [CrossRef]

83. DaVanzo, R.; Merewood, A.; Manzoni, P. Skin-to-Skin Contact at Birth in the COVID-19 Era: In Need of Help! Am. J. Perinatol. 2020, 37, S1-S4. [CrossRef] [PubMed] 